\title{
FORMA CZYNNOŚCI PRAWNEJ W PRAWIE PRYWATNYM MIĘDZYNARODOWYM
}

\section{UWAGI WSTĘPNE}

Kolizyjnoprawne spojrzenie na formę czynności prawnych wymaga oderwania się od własnego prawa merytorycznego. Współcześnie forma czynności prawnej oraz zdolność osób fizycznych i prawnych są regulowane zwykle w odrębnych normach kolizyjnych. Kwestie te są więc wyłączone z zakresu zastosowania prawa właściwego dla czynności prawnej (statutu czynności prawnej) $\mathrm{w}$ powiązaniu $\mathrm{z}$ którą zagadnienie formy lub zdolności jest rozpatrywane.

Wyrażenie forma występuje więc dziś w przepisach prawa prywatnego międzynarodowego $\mathrm{w}$ roli pojęcia określającego zakres normy kolizyjnej wskazującej prawo właściwe dla formy czynności prawnych (statut formy).

W doktrynie wielu jej przedstawicieli podkreśla, że niemożliwe jest zbudowanie ogólnego kolizyjnoprawnego pojęcia formy ${ }^{1}$. Niesposób też wskazać precyzyjne kryteria za pomocą których da się wytyczyć zakres zastosowania statutu formy (dokonać odgra-

' Por. A. MĄCZYŃSKI, Dziedziczenie testamentowe w prawie prywatnym międzynarodowym. Ustawowe i konwencyjne uregulowanie problematyki formy, Kraków 1976, s. 66 i n. oraz poglądy tam omawiane. 
niczenia tego statutu od statutów innych). Z tymi twierdzeniami trzeba się zgodzić.

Poprzestać więc trzeba na zarysowaniu jedynie ogólnych konturów pojęcia formy. To jest nie tylko możliwe, ale i celowe. Ogólnie ujęte objaśnienie formy w rozumieniu prawa prywatnego międzynarodowego może być przydatne przy rozstrzyganiu kwestii szczegółowych w trakcie stosowania prawa. Jego bazę powinny stanowić wyniki badań prawnoporównawczych.

Trzeba też pamiętać o funkcjach norm kolizyjnych, a zwłaszcza o tym, iż rozgraniczają one zasięg systemów prawnych różnych państw w przestrzeni. Z natury rzeczy stykają się więc z konstrukcjami pojęciowymi występującymi w różnych porządkach prawnych.

Wychodząc z tych założeń można stwierdzić, iż wyrażenie forma, występujące w przepisach kolizyjnych, oznacza wymagania określające sposób złożenia oraz ucieleśnienia oświadczenia woli² ${ }^{2}$ będącego nieodzownym (koniecznym) elementem składowym stanu faktycznego nazywanego czynnością prawną. Obejmują one utrwalenie oświadczenia woli złożonego ustnie, wymaganie zachowania zwykłej lub kwalifikowanej formy pisemnej, opatrzenie pieczęcią dokumentu na którym oświadczenie woli zostało utrwalone, wymaganie własnoręcznego podpisu, udział świadków przy dokonaniu czynności prawnej lub też udział przy złożeniu oświadczenia woli osoby urzędowej albo organu państwowego. Jest to oczywiście wyliczenie jedynie przykładowe.

\section{PRÓBY UJEDNOLICENIA UNORMOWANIA FORMY}

Zacząć wypada od jednolitej ustawy o zawieraniu umów międzynarodowej sprzedaży materialnych przedmiotów ruchomych z 1964 r. ${ }^{3}$

${ }^{2}$ Por. A. Mączyński, Dziedziczenie, cit., s. 74 i n.; W. PopIOŁeK, Umowa wydawnicza w polskim prawie prywatnym międzynarodowym, Kraków 1982, s. 106; M. PAZDAN, Prawo prywatne międzynarodowe, Warszawa 2005, s. 111.

${ }^{3}$ Przekład polski w zbiorze pt. Problemy prawne handlu zagranicznego. Wybór źródet, bibliografia, w oprac. M. PAZDANA, Katowice 1976, s. 164-168. 
W myśl art. 3 ustawy oferta i przyjęcie oferty nie wymagają żadnych formalności. W szczególności mogą być one dowodzone za pomocą świadków.

Konwencję ratyfikowała jedynie Wielka Brytania, dlatego też nie weszła ona w życie ${ }^{4}$.

Także art. 1 projektu Unidroit prawa jednolitego z 1977 r. stanowi, iż zawarcie umowy nie wymaga żadnej formy, chyba że ustawa lub strony postanowią inaczej.

Zasadę braku formalizmu przy zawieraniu umów sprzedaży w obrocie międzynarodowym wyraża art. 11 konwencji Narodów Zjednoczonych o umowach międzynarodowej sprzedaży towarów, sporządzonej w Wiedniu 11 kwietnia 1980 r., która w stosunku do Polski weszła w życie dnia 1 czerwca 1996 r. ${ }^{6} \mathrm{~W}$ dalszych wywodach, nazywana ona będzie konwencją wiedeńską. W myśl art. 11 zd. 1 konwencji umowa sprzedaży nie wymaga do jej zawarcia lub potwierdzenia formy pisemnej i nie podlega żadnym innym wymogom co do formy. $\mathrm{Z}$ kolei według art. $11 \mathrm{zd}$. 2 umowa sprzedaży może być udowodniona $w$ jakikolwiek sposób, w tym również na podstawie zeznań świadków. Obok więc zasady braku formalizmu odnajdujemy w omawianym przepisie zasadę dopuszczalności wszelkich środków dowodowych (z zeznaniami świadków włącznie) przy dowodzeniu zarówno faktu zawarcia, jak i treści umowy.

To rozwiązanie harmonizuje ze stanowiskiem prawa krajowego większości państw na świecie oraz odpowiada potrzebom praktyki międzynarodowego obrotu handlowego?

+ Sygnatariuszami konwencji były państwa: Grecja, Holandia, Wielka Brytania, San Marino, Włochy, Watykan, Belgia, RFN, Luksemburg, Węgry, Izrael i Francja. Por. Y. LoussouARn, J. D. BREdin, Droit du commerce international, Paris 1969, s. 937 i n.

${ }^{5}$ Por. Rapport explicatif opracowany przez Sekretariat Unidroit, Etude L-Doc. 11, Unidroit 1977, s. 7.

${ }^{\circ}$ Oświadczenie rządowe z 25 października 1996 r., Dz.U. z 1997 r. Nr 45, poz. 287.

${ }^{7}$ Por. J. RAJSKI, [w:] Commentary on the International Sales Law. The 1980 Vienna Sales Convention, (red.) C. M. BianCA, M.J. Bonell, Milan 1987, s. 122 i n. (nr 2). 
Zasada braku formalizmu rozpościera się także na zmianę, uzupełnienie oraz rozwiązanie umowy (por. art. 29 konwencji) ${ }^{8}$.

Przyjęte w konwencji rozwiązanie sprawia, że rozstrzygnięć co do formy należy w odniesieniu do umowy sprzedaży poszukiwać głównie w postanowieniach konwencji. Czyni to zbędnym zwracanie się do miarodajnych w zakresie formy norm kolizyjnych prawa prywatnego międzynarodowego w celu znalezienia prawa w tej mierze właściwego.

Zwrócić jednak trzeba uwagę na art. 96 konwencji zezwalający państwu, którego prawo wymaga, aby umowa sprzedaży była zawarta lub potwierdzona na piśmie, na złożenie (w każdej chwili, a więc także po ratyfikacji konwencji) oświadczenia - zgodnie z art. 12 - że (m.in.) postanowienie art. 11 nie będzie miało zastosowania w sytuacji gdy jedna ze stron umowy ma swoją siedzibę handlową w tym państwie?.

Na szczęście dotychczas tylko kilka państw możliwość tę wykorzystało. Znalazły się wśród nich: Argentyna, Białoruś, Chile, Chiny, Estonia, Litwa, Rosja, Ukraina, Węgry. Zgłoszenie zastrzeżenia nie oznacza jednak z góry właściwości w zakresie formy prawa państwa, które zastrzeżenie zgłosiło. Właściwość ta musi bowiem wynikać z norm kolizyjnych miarodajnych dla formy, obowiązujących w państwie forum ${ }^{10}$.

\section{U POCZĄTKÓW KOLIZYJNOPRAWNYCH REGUŁ DOTYCZĄCYCH FORMY}

Pod wpływem czynników gospodarczych i politycznych, począwszy od XI wieku, zaczęto przełamywać panującą wcześniej zasadę terytorializmu. Stało się to zasługą przedstawicieli tzw. dawnej szkoły sta-

${ }^{8}$ Szerzej na temat art. 29 konwencji J. PAZDAN, [w:] Konwencja wiedeńska o umowach międzynarodowej sprzedaży towarów. Komentarz, Zakamycze 2001, s. 338 i n.; I. SAenger, [w:] Kommentar zum Bürgerlichen Gesetzbuch. Hrsg. H.G. BAmberger, H. Roth., III, München 2003, s. 2805 i n.

${ }^{9}$ Szerzej na ten temat M. PAZDAN, [w:] Konwencja wiedeńska, cit., s. 761 i n.

${ }^{10}$ Por. J. RAJSKI, [w:] Commentary on the International Sales Law, cit., s. 659 i n.; M. PAZDAN, [w:] Konwencja wiedeńska, cit., s. 763. 
tutowej, nazywanej czasem nieściśle dawną szkołą włoską (wśród jej przedstawicieli znaleźli się bowiem nie tylko wybitni prawnicy z ośrodków włoskich, lecz również z ośrodków francuskich).

Jedna $\mathrm{z}$ najstarszych reguł kolizyjnych dotyczy właśnie formy czynności prawnej. Wyraża ją paremia locus regit formam actus ${ }^{11}$. Forma podlega zatem prawu państwa, w którym czynność ma być, jest lub została dokonana.

$\mathrm{Za}$ autora tej reguły uchodzi profesor z Tuluzy Wilhelm de Cun (Guilelmus de Cuneo, pierwsza połowa XIV wieku) ${ }^{12}$. Przyjmował ją również mistrz Bartolusa Cinus de Pistoia (1270-1336) ${ }^{13}$ oraz sam Bartolus de Sassoferrato (1314-1357) ${ }^{14}$, nazywamy przesadnie ojcem nauki prawa prywatnego międzynarodowego. Główną jego zasługą było bowiem uporządkowanie i usystematyzowanie wcześniejszego dorobku obu romańskich nurtów (włoskiego i francuskiego). Obok statutów osobowego i rzeczowego wyróżnił on statuty obejmujące formę (formę przeciwstawiał treści czynności), utrwalając na wiele wieków wspomnianą już regułę locus regit actum. Regułą tą objął także czynności zdziałane przez cudzoziemców na obcym terytorium, jednocześnie nadał jej charakter bezwzględnie wiążący (in solemnitatibus semper inspicimus locum ubi res agitur). Otworzyło to drogę do respektowania aktów dokonanych zgodnie z prawem miejsca dokonania, przed powołaną do tego (przez to prawo) władzą.

Regułę locus regit actum akceptował Charles Dumoulin (Molinaeus, $1500-1566)^{15}$.

${ }^{11}$ Por. G.S. MARIDAKIS, Introduction au droit international privé, Leyde 1962 (odbitka z Recueil des Cours 1962), s. 492.

${ }_{12}$ Por. E.M. MeIJers, Études d'histoire du droit international privé, Paris 1967, s. 95 i n.; M. GuTZWILLER, Geschichte des Internationalprivatrechts. Von den Anfangen bis zu den grossen Kodifikationen, Basel-Stuttgart 1977, s. 19 przyp. 30.

${ }^{13}$ Por. R. SchÖNWERTH, Die Form der Rechtsgeschäfte im internationalen Privatrecht-Art. 11 EG BGB, Frankfurt a. M. 1996, s. 73.

${ }^{14}$ C. Zellweger, Die Form der schuldrechtlichen Verträge im internationalen Privatrecht, Basel-Frankfurt a. M. 1990, s. 25, 32 i n,; R. SCHÖNWERTH, op. cit., s. 73 i n.

${ }^{15}$ Por. F. Gamillscheg, Der Einfluss Dumoulins auf die Entwicklung des Kollisionsrechts, Berlin-Tübingen 1955, s. 22 przyp. 13. 
Zasadę, że czynność spełniająca wymagania obowiązujące w miejscu jej dokonania powinna być wszędzie ważna wyznawał wybitny przedstawiciel szkoły holenderskiej Ulricus Huber $(1636-1694)^{16}$.

Dopiero Friedrich Carl von Savigny (1779-1861), twórca nowoczesnego prawa prywatnego międzynarodowego, utrzymując zasadę locus regit actum zaproponował od niej odstępstwo. Według niego przy dokonaniu czynności można zachować wymagania co do formy obowiązujące w miejscu jej dokonania, wystarczające jest jednak również dopełnienie wymagań przewidzianych przez prawo miejsca, w którym stosunek prawny ma swoją siedzibę (właściwość legis causae), jeżeli wymagania te są inne ${ }^{17}$.

\section{SPOSOBY REGULACJI WŁAŚCIWOŚCI PRAWA W ZAKRESIE FORMY} W CZASACH WSPÓŁCZESNYCH

Kolizyjnoprawne unormowania formy czynności prawnej są niezwykle zróżnicowane. Najczęściej chodzi tu o regulacje krajowe. Chlubne wyjątki w postaci unormowań konwencyjnych nie są liczne. Przykładowo wymienić trzeba konwencję haską z 1961 r. dotyczącą formy rozrządzeń testamentowych ${ }^{18}$ oraz konwencję rzymską z 1980 r. o prawie właściwym dla zobowiązań umownych ${ }^{19}$, która jednak jest konwencją dostępną jedynie dla państw członkowskich

${ }^{16}$ Por. M. Gutzwiller, op. cit., s. 155 i n.; C. Zellweger, op. cit., s. 56; R. SCHÖNWERTH, op. cit., s. 76 i n.

${ }^{17}$ F.C. SaVIGNY, System des heutigen römischen Rechts, VIII, Berlin 1840, s. 350 i n.

${ }^{18}$ Dz.U. z 1969 r. Nr 34, poz. 284. Weszła ona w życie w stosunku do Polski 2 listopada 1969 r. (oświadczenie rządowe z 19 listopada 1969 r., Dz.U. Nr 34, poz. 285). Na jej temat por. w szczególności A. MĄCZYŃSKI, Dziedziczenie, cit., s. 43 i n.

${ }^{19}$ Tekst polski w tłumaczeniu W. PopıOŁKA ogłoszony w «Pr. Nauk. UŚl. -Probl. Praw. Handl. Zagr.» 7 (1983), s. 124 i n. oraz w «KPP» 3.2 (1994), s. 300-341; por. również tamże omówienie W. PopiołKa (s. 297-299). Por. też A. CaŁus, Wybrane problemy wprowadzenia do systemów prawnych państw członkowskich Unii Europejskiej postanowień konwencji rzymskiej o prawie wtaściwym dla zobowiqzań umownych, «Pr. Nauk. UŚl. - Probl. Praw. Handl. Zagr.» 18 (1995), s. 24-58. 
Unii Europejskiej. Już wkrótce - po zakończeniu procedury ratyfikacyjnej - zacznie ona obowiązywać także w Polsce.

Nie sposób referować tutaj treść przepisów kolizyjnych różnych państw dotyczących formy. Ograniczę się do przykładów, ujmując je w odpowiednie grupy. Obok reguł ogólnych przedstawię też niektóre reguły szczególne.

Kolizyjne unormowania formy ująć można w następujące trzy grupy:

a) Do grupy pierwszej należą systemy prawne wedle których forma podlega zasadniczo legi causae. Wystarczy jednak dopełnić wymagania przewidziane przez prawo państwa, w którym czynność została dokona (lex loci actus).

Rozwiązanie do przyjęto m.in.: w Austrii (\$ 8 ustawy z 1978 r. $)^{20}$, Lichtensteinie ( $\$ 8$ ustawy z 1996 r.) ) $^{21}$ i Polsce (art. 12 ustawy z 1965 r. $^{22}$; wcześniej art. 5 ustawy z 1926 r. $^{23}$, z wyjątkiem art. 6 ust. 3 na rzecz wyłącznej właściwości prawa polskiego, jeżeli czynność prawna zobowiązująca lub rozporządzająca dotyczyła nieruchomości położonej w Polsce).

b) Grupa druga obejmuje systemy prawne, które na czoło wysuwają zasadę właściwości legis loci actus, przewidują jednak od tej zasady odstępstwa. Są one rozmaicie ujmowane. Przykładu pierwszego dostarcza ustawa Quebec z $1993 \mathrm{r}^{24}$ wedle której dla formy właściwa jest lex loci actus, ale wystarczy, że czynność prawna czyni zadość wymaganiom w zakresie formy przewidzianym w innym prawie, a mianowicie:

${ }^{20}$ Bundesgesetzblatt für die Republik Österreich 1978 cz. 109 poz. 304; tłumaczenie francuskie $w$ «Revue critique de droit international privé» 1979 nr 1, s. 176-184 ze wstępem F. SCHWINDA.

${ }^{21}$ Tekst ogłoszono w «Revue critique de droit international privé» $1997 \mathrm{nr} 4$, s. $858-873$.

${ }^{22}$ Dz.U. Nr 46, poz. 290 z późn. zm.

${ }^{23}$ Dz.U. Nr 101, poz. 581 z późn. zm.

${ }^{24}$ Por. H.P. GLEnN, Codification of Private International Law in Québec - an overview, «IPRax» 1994 z. 4, s. 308 i n. 
1) prawie właściwym dla czynności prawnej (lex causae),

2) prawie miejsca położenia dobra stanowiącego przedmiot czynności prawnej, lub

3) prawie domicylu którejkolwiek ze stron w chwili dokonania czynności prawnej.

Podgrupę drugą tworzą systemy prawne według których forma podlega zasadniczo legi loci actus, jednakże czynność prawna dokonana za granicą nie może być uznana za nieważną, jeżeli czyni zadość wymaganiom (co do formy) własnego prawa.

Do tej podgrupy należą: Rosja (art. 1209 ust. 1 k.c. z 2001 r. $)^{25}$, Białoruś (art. 1116 ust. 1 k.c.) $)^{26}$, Kazachstan (art. 1104 ust. 1 k.c. z 1999 r.) ${ }^{27}$ i Azerbejdżan (art. 17 ust. 1 k.c. z 2000 r.) ${ }^{28}$.

Przykład podgrupy trzeciej w grupie drugiej to prawo czechosłowackie i obowiązujące dziś w Czechach i Słowacji $1^{29}$. W myśl § 4 zd. 2 ustawy czechosłowackiej z $1963 \mathrm{r}$. forma podlega legi loci actus (prawu miejsca złożenia oświadczenia woli), chyba że lex causae wymaga formy pisemnej ad solemnitatem. Wówczas ta forma musi być zachowana.

c) I wreszcie grupa trzecia posługująca się konstrukcją właściwości w pełni alternatywnej. Wystarcza mianowicie dopełnić wymagania przewidziane w:

1) lex causae lub lex loci actus (np. art. 11 ust. 1 i 2 ustawy niemieckiej z 1986 r. ${ }^{30}$, art. 124 ust. 1 ustawy szwajcarskiej

${ }^{25}$ Tłumaczenie francuskie ogłoszono $\mathrm{w}$ «Revue critique de droit international privé» 2002 nr 1, s. 182-192. Por. też A.K. SuBCZYŃSKA-ŁAZARZ, Rosyjskie prawo prywatne międzynarodowe, «KPP» 11.2 (2002), s. 501 i n.

${ }^{26}$ Por. W.F. CzIGIR (red.), Komentarij k grażdanskomu kodeksu Respubliki Bieloruś, II, Mińsk 1999, s. 596 i n.

${ }_{27}$ Tłumaczenie niemieckie ogłoszono w «IPRax» 2002 z. 1, s. 55-58. Por. A. WeISHAupt, Neues Kollisions - und Iternationales Zivilprozessrecht in der Republik Kazachstan, «IPRax» 2002 z. 1, s. 53 i n.

${ }^{28}$ Tłumaczenie niemieckie ogłoszono w «IPRax» 2003 z. 4, s. 386-389.

29 Tłumaczenie na język polski ogłosił J. PoczoBUT, Źródta prawa prywatnego międzynarodowego, Warszawa 1992, s. 17.

${ }^{30}$ Bundesgesetzblatt 1986, Nr 37, s. 1142-1155.

${ }^{31}$ Bundesblatt 1989, cz. I, s. 5 i n. 
z 1987 r..$^{31}$, art. 7 ustawy słoweńskiej z 1999 r..$^{32}$, art. 548 ust. 2 k.c. mongolskiego z 2002 r. $^{33}$ oraz art. 9 ust. 2 konwencji rzymskiej z 1980 r.),

2) lex causae, lex loci actus lub wspólnym prawie ojczystym (np. k.c. grecki z $1940 \mathrm{r}^{34}$, ustawa albańska z $1964 \mathrm{r}^{35}$ ).

Pierwsze $z$ tych rozwiązań przewiduje również art. $21 \S 1$ projektu ustawy o prawie prywatnym (w wersji roboczej z 2004 r.), przygotowanego przez Zespół prawa prywatnego międzynarodowego Komisji Kodyfikacyjnej Prawa Cywilnego.

Zamierzenie to zasługuje na wsparcie. Dziś bowiem na świecie w zakresie formy poszukuje się rozwiązań działających in favorem negotii, a takim ono jest.

Przy poszukiwaniu sankcji w razie niezachowania wymagań w zakresie formy wynikających zarówno z legis causae, jak i z legis loci actus, trzeba będzie uciekać się do stosowania tego prawa, które przewiduje sankcję łagodniejszą.

Unormowania ogólne formy w wielu systemach prawnych uzupełniają lub modyfikują reguły szczególne.

a) Szczególną normę dotyczącą sytuacji, gdy umowa dochodzi do skutku między osobami znajdującymi się w różnych państwach (inter absentes) znajdujemy m.in. w prawie niemieckim (art. 11 ust. 1 ustawy z 1986 r., mongolskim (art. 548 ust. 3 k.c. z 2002 r.) oraz w konwencji rzymskiej z 1980 r. W myśl art. 9 ust. 2 tej konwencji wystarczy że umowa czyni zadość wymaganiom co do formy przewidzianym przez prawo właściwe na podstawie konwencji (lex causae) lub przez prawo jednego z państw, w któ-

${ }^{32}$ Por. M. GeÖ-KorošEc, Die Reform des slowenischen Internationalen Privatrecht und Verfahrensrechts und seine Anpassung an das Recht der Europäischen Union, «Rabels Zeitschrift» 2002 z. 4, s. 715.

${ }^{33}$ Tłumaczenie niemieckie ogłoszono w «IPRax» 2003 z. 4, s. 381-386.

${ }^{34}$ Tłumaczenie niemieckie [w:] IPR-Gezetze in Europa. Hrsg. W. RIERING, München 1997, s. 19 i n.

${ }^{35}$ Tłumaczenie na język polski ogłosił J. PoczoBuT, Kodyfikacje prawa prywatnego międzynarodowego, Warszawa 1991, s. 11-16. 
rym osoby zawierające umowę w chwili zawarcia umowy znajdują się.

b) W licznych systemach prawnych w sposób szczególny traktowane są czynności prawne dotyczące nieruchomości. To szczególne traktowanie wyrażają jednak rozmaicie ujęte formuły. Oto ich przykłady:

1) bezwzględnie obowiązujące przepisy o formie prawa państwa, w którym nieruchomość jest położona, stosuje się o tyle, o ile przepisy te, według prawa tego państwa należy stosować bez względu na miejsce zawarcia umowy i prawo dla niej właściwe (tak art. 9 ust. 6 konwencji rzymskiej z 1980 r., art. 11 ust. 4 ustawy niemieckiej z 1986 r., art. 17 ust. 3 ustawy azerbejdżańskiej z 2000 r.),

2) forma czynności prawnych dotyczących nieruchomości podlega legi rei sitae (tak art. 1209 ust. 3 k.c. rosyjskiego z 2001 r., art. 1104 ust. 3 k.c. kazachskiego z 1999 r., art. 1116 ust. 3 k.c. białoruskiego),

3) forma czynności prawnych dotyczących nieruchomości położonych na obszarze własnego państwa podlega jego prawu (tak art. 615 ust. 3 k.c. litewskiego z 1994 r. ${ }^{36}$, art. 548 ust. 5 k.c. mongolskiego z 2002 r.),

c) Spotkać można również unormowanie w myśl którego czynności prawne handlu zagranicznego $\mathrm{z}$ udziałem własnych osób prawnych lub fizycznych wymagają zachowania formy przewidzianej przez własne prawo (np. art. 1209 ust. 2 k.c. rosyjskiego z 2001 r., art. 1116 ust. 2 k.c. białoruskiego).

\section{WŁAŚCIWOŚĆ LEGIS CAUSAE (REGUŁA PIERWSZA Z ART. 12 USTAWY Z 1965 R.)}

W myśl art. 12 naszej ustawy z 1965 r. „forma czynności prawnej podlega prawu właściwemu dla tej czynności; wystarcza jednak zachowanie formy przewidzianej przez prawo państwa, w którym czynność zostaje dokonana”. Według zgodnej opinii

\footnotetext{
${ }^{36}$ Por. tłumaczenie na język niemiecki i omówienie - E. JAYME, Zum Stand des Internationalen Privatrechts in Litauen, «IPRax» 1997 z. 5, s. 351-352 oraz 371-373.
} 
naszej doktryny ${ }^{37}$, jeżeli przy dokonaniu czynności prawnej nie zachowano ani wymagań w zakresie formy przewidzianych przez prawo dla niej właściwe, ani wymagań, które ustanawia prawo państwa na obszarze którego czynność prawna została dokonana, skutki niezachowania formy należy oceniać według prawa właściwego dla czynności prawnej. Decyduje więc lex causae. Rozwiązanie to należy przyjąć także wtedy, gdy wymóg co do formy ustanowiony przez prawo miejsca dokonania czynności prawnej (lex loci actus) jest wymogiem pod rygorem ograniczeń dowodowych (forma ad probationem), natomiast lex causae przewiduje $\mathrm{w}$ danym przypadku formę pod rygorem nieważności (forma ad solemnitatem).

Przytoczony pogląd dowodzi, iż regułę właściwości legis loci actus na tle prawa polskiego trzeba traktować jako regułę subsydiarną.

Należy też - jak się wydaje - przyjąć, iż powyższa reguła nie nadaje się do stosowania, gdy zawarcie umowy następuje inter absentes, a strony umowy znajdują się w tym czasie w różnych państwach $^{38}$. W takim bowiem przypadku ustalenie rzeczywistego miejsca zawarcia umowy nie jest możliwe, a miejsce ustalone przy zastosowaniu odpowiedniej wskazówki zaczerpniętej z krajowego

${ }^{37}$ Por. K. PrzybyŁowsKI, Kodyfikacyjne zagadnienia prawa międzynarodowego prywatnego, «Studia Cywilistyczne» 5 (1964), s. 25; TENŻE, Nowe polskie unormowania problematyki kolizyjnej prawa prywatnego międzynarodowego, "Studia Cywilistyczne» 8 (1966), s. 23; A. MĄCZYŃski, Dziedziczenie, cit., s. 27; B. WALASZEK, M. SośNIAK, Zarys prawa prywatnego międzynarodowego, Warszawa 1973, s. 144; W. PoPIOŁEK, Umowa wydawnicza, cit., s. 104; W. LuDWICZAK, Międzynarodowe prawo prywatne, Warszawa 1979, s. 148; E. WIERZBOWSKI, Międzynarodowy obrót prawny w sprawach cywilnych, Warszawa 1971, s. 237-238; M. SoŚNIAK, Prawo prywatne międzynarodowe, Katowice 1978, s. 132; H. TRAMMER, Sprawy czysto majątkowe w polskim prawie prywatnym międzynarodowym, «Prawo w Handlu Zagranicznym» 1968 nr 19-20, s. 30; M. Pazdan, Prawo, cit., s. 111. Odosobniony pogląd wyraził J. BALICKI, Międzynarodowe prawo prywatne, Lublin 1976, s. 93, którego zdaniem mniej dogmatyczne jest rozwiązanie w myśl którego „należy wyciągnąć te konsekwencje, które są łagodniejsze, mniej dotkliwe dla uczestników danej czynności prawnej”.

${ }^{38}$ Por. W. Popiolek, Umowa wydawnicza, cit., s. 105; M. Pazdan, Prawo, cit., s. 111. 
(własnego lub obcego) systemu prawnego, odznacza się sztucznością. Powątpiewać należy w jego przydatność do spełniania roli łącznika normy kolizyjnej.

Z ostrożnością natomiast, w zakresie zobowiązań umownych, należy posługiwać się zasadą, iż stosowanie reguły locus regit actum jest wykluczone, gdy lex loci nie zna umowy tego typu, co umowa przewidziana i podlegająca (innej) legi contractus. Pamiętać bowiem trzeba o szeroko dopuszczalnej właśnie w zakresie zobowiązań umownych swobodzie kontraktowej stron, dzięki której strony mogą zawierać umowy nienazwane. $\mathrm{Z}$ faktu, iż według legis loci actus dana umowa jest jedynie umową nienazwaną nie zawsze należy wnosić o niedopuszczalności posługiwania się w zakresie formy regułą locus regit actum. Przy bliższej analizie może się bowiem okazać, że w prawie miejsca zawarcia umowy obowiązują ogólne normy dotyczące formy, obejmujące również określone postacie umów nienazwanych. Trzeba więc raczej badać jakie wymagania z prawa obowiązującego w miejscu zawarcia umowy wynikają dla określonej grupy umów do której można by zaliczyć również umowę dla której poszukujemy rozstrzygnięcia.

Norma z art. 12 ustawy z 1965 r., przewidująca właściwość legis causae, kieruje nas bezpośrednio ku prawu merytorycznemu właściwemu dla czynności prawnej o formę której chodzi. Nie bierze się więc pod uwagę treści norm kolizyjnych miarodajnych dla formy czynności prawnej, wchodzących w skład prawa właściwego dla danej czynności prawnej. Poprzez lex causae nie może więc dojść do odesłania w zakresie formy.

Samo prawo właściwe dla danej czynności prawnej (czyli sama lex causae) może być jednak ustalona w drodze odesłania, jeżeli odesłanie jest w określonym zakresie dopuszczalne i spełnione są jego przesłanki.

Dodajmy też, iż owa lex causae mająca znaczenie na podstawie art. 12 zd. 1 ustawy z 1965 r. w zakresie formy, może być wskazana nie tylko za pośrednictwem norm kolizyjnych posługujących się łącznikami obiektywnymi, lecz również w drodze wyboru prawa (jeśli wybór prawa jest dla danej czynności prawnej dopuszczalny). 
Nie ulega zaś wątpliwości, iż wybór prawa dla samej formy czynności prawnej jest niedopuszczalny.

W rozważanym kontekście pojawia się pytanie, czy należy dopuścić wybór prawa ograniczony jedynie do formy czynności prawnej z odwołaniem się do tezy o dopuszczalności częściowego kolizyjnoprawnego wyboru. Miałby to być wybór tego fragmentu legis causae, który brany jest pod uwagę przy ustalaniu wymagań dotyczących formy czynności prawnej, na podstawie art. $12 \mathrm{zd}$. 1 ustawy z $1965 \mathrm{r}$.

Wydaje się, że na postawione wyżej pytanie należy udzielić odpowiedzi przeczącej ${ }^{39}$. Nie ma bowiem fragmentu legis causae stosowanej w zakresie formy, lecz jest lex causae pełna lub podzielona na segmenty (w razie złożonego lub częściowego wyboru prawa), ale segmentu takiego forma stanowić nie może. Ona bowiem ma swój własny statut.

Odwołanie się w art. 12 zd. 1 ustawy z 1965 r. do legis causae jest więc odwołaniem się wyłącznie do prawa merytorycznego, któremu dana czynność prawna podlega.

W razie złożonego wyboru prawa (poddania umowy kilku systemom prawnym) sąd stosujący prawo powinien formę przyporządkować do zakresu zastosowania jednego z wybranych systemów prawnych. Istotną wskazówkę w tej mierze może stanowić wola wyrażona przez strony w akcie wyboru prawa. Jeżeli więc jeden $\mathrm{z}$ systemów prawnych - wedle życzenia stron - jest właściwy do oceny ważności umowy, a drugi do oceny jej skutków, jest oczywiste, że formę obejmuje pierwszy system prawny.

${ }^{39}$ Por. D. Furgler, Die Anknüpfung der Vertragsform im internationalen Privatrecht, Zürich 1985, s. 99 i n.; G. HohLOCH, [w:] ERMAN. Bürgerliches Gesetzbuch $^{10}$, Hrgb. H.P. WestermanN, Münster-Köln 2000, s. 5203 nb 9; P. Winkler von MoHrenfels, [w:] J. von Staudingers Kommentar zum Bürgerlichen Gesetzbuch mit Einführungsgesetz und Nebengesetzen. Art. 7, 9, 10, 11, 12 EG BGB, (red.) J. Kropholler, Berlin 2000, s. 354 i 355 nb 31; J. PAZDAN, Petnomocnictwo $w$ prawie prywatnym międzynarodowym, Zakamycze 2003, s. 134. 
VI. WŁAŚCIWOŚĆ LEGIS LOCI ACTUS (REGUŁA DRUGA Z ART. 12 USTAWY Z 1965 R.)

Reguła druga z art. 12 (zd. 2) naszej ustawy z 1965 r. w myśl której wystarcza zachowanie formy przewidzianej przez prawo państwa, w którym czynność została dokonana, działa uzupełniająco w stosunku do reguły pierwszej. Profesor Andrzej Mączyński właściwość legis loci actus na podstawie art. 12 nazywa właściwością „ratunkową"40. Ten typ relacji obu reguł pociąga za sobą szereg następstw. Oto one:

1) Lex loci actus należy stosować dopiero wtedy, gdy nie zachowano wymagań wynikających z lex causae $e^{41}$.

2) Właściwość legis loci actus jest uzależniona od tego, czy przy dokonaniu czynności prawnej zachowano wymagania wynikające $\mathrm{z}$ tego prawa.

3) W razie niezachowania wymagań co do formy przewidzianych zarówno przez lex causae, jak i przez lex loci actus o skutkach niezachowania formy (czyli o sankcji) rozstrzyga lex causae (była już o tym wyżej mowa).

4) Lex loci actus nie może być zastąpiona przez prawo polskie na podstawie art. 7 ustawy z 1965 r., gdy nie można ustalić treści prawa obowiązującego w miejscu dokonania czynności prawnej.

5) W doktrynie wyklucza się możliwość odesłania na podstawie norm kolizyjnych obowiązujących w państwie, w którym czynność jest dokonana i to zarówno odesłania dalszego, jak i zwrotnego ${ }^{42}$.

6) Wypada też dodać, iż do zachowania wymagań legis loci actus dochodzi także wtedy, gdy prawo to nie przewiduje obowiązku zachowania jakiejkolwiek, określonej formy ${ }^{43}$. Czynność prawna będzie w takiej sytuacji ważna mimo że nie zachowano wymagań co do formy wynikających z lex causae.

\footnotetext{
${ }^{40}$ A. MĄCZYŃSKI, Dziedziczenie, cit., s. 27.

${ }^{4}$ Por. A. MĄCZYŃski, Dziedziczenie, cit., s. 27.

${ }^{42}$ Por. A. MĄCZYŃski, Dziedziczenie, cit., s. 28 i 29.

${ }^{43}$ Por. A. MĄCZYŃsKi, Dziedziczenie, cit., s. 29-31.
} 
7) Możliwość (dopuszczona przez regułę 2) dopełnienia wymagań przewidzianych w lex loci actus nie ma nic wspólnego z kolizyjnoprawnym wyborem prawa ${ }^{44}$.

Co do rozumienia pojęcia miejsca dokonania czynności prawnej występującego w roli łącznika w art. 12 zd. 2 ustawy z 1965 r. uzasadniona wydaje się kwalifikacja autonomiczna. W tym też kierunku podąża polska doktryna ${ }^{45}$. Poszukuje ona samodzielnych rozstrzygnięć, dystansując się od wskazówek udzielanych przez przepisy prawa merytorycznego (np. art. $70 \S 2$ polskiego k.c.).

Proponuje się więc by - w przypadku umowy - poszukiwać państwa z którego obszarem zawarcie umowy jest najściślej związane ${ }^{46}$. Decydujące znaczenie należy więc przyznać miejscu w którym doszło do zaszłości (zdarzenia), które - w ramach procedury zawarcia umowy - doprowadziły (lub doprowadzić miały) do powstania stosunku umownego. Chodzi o miejsce w którym nastąpiły zaszłości o największym znaczeniu dla zawarcia umowy.

W przypadku czynności prawnych jednostronnych - chodzi o miejsce złożenia oświadczenia woli przez dokonującego czynności prawnej (miejsce jego zachowania się wyrażającego wolę).

\section{STATUT FORMY A STATUTY INNE}

1. Przy poszukiwaniu odpowiedzi na pytanie, czy jakaś kwestia należy do zakresu statutu formy, czy też do statutu innego należy rozważyć - po pierwsze - jakie cele poprzez uregulowanie określonej kwestii ustawodawca, starał się osiągnąć, czy takie jakie przyświecają w tym prawie przepisom o formie czy też inne oraz - po drugie - czy za stosowaniem do owej kwestii nie tylko legis causae, lecz także legis loci actus, przemawiają te same argumenty, których

\footnotetext{
${ }^{44}$ Por. A. Mączyński, Dziedziczenie, cit., s. 32.

${ }^{45}$ Por. M.A. Zachariasiewicz, W. PopiołeK, Znaczenie pojęć „chwila” $i$ „miejsce zawarcia umowy" w ustawie o prawie prywatnym międzynarodowym, «Pr. Nauk. UŚl. - Probl. Praw. Handl. Zagr.» 5 (1981); M. PAZDAN, Prawo, cit., s. 112.

${ }^{46}$ Por. M.A. Zachariasiewicz, W. PopioŁeK, op. cit., s. 101 i 102.
} 
używa się w argumentacji na rzecz poddania formy także legi loci actus (a nie tylko legi causae).

Doświadczenie judykatury i doktryny związane $z$ odgraniczaniem statutu formy od innych statutów są dość bogate. Ograniczę się do przytoczenia jedynie kilku przykładów.

2. Jeden z bardziej znanych przypadków to wątpliwości dotyczące stosowania art. 992 dawnego k.c. holenderskiego (z 1838 r. $)^{47}$. Przepis ten postanawiał, że obywatel holenderski przebywający poza Holandią, może sporządzić testament tylko w formie urzędowej, zgodnej z prawem obowiązującym w miejscu jego sporządzenia, nie może natomiast korzystać z miejscowej formy holograficznej. Dodajmy, że testament holograficzny według dawnego prawa holenderskiego wymagał do swej ważności nie tylko osobistego spisania i podpisania oświadczenia woli przez testatora, lecz nadto osobistego złożenia testamentu u notariusza, który w obecności dwóch świadków spisywał akt sporządzenia testamentu. E. Bartin w związku z tym postawil pytanie czy tego rodzaju zakaz korzystania $z$ formy własnoręcznej testamentu należy do zakresu statutu formy, czy też do zakresu statutu personalnego (obejmującego zdolność) ${ }^{48}$. Przykładu tego użył do ilustracji tzw. konfliktu kwalifikacyjnego. Licząc się z takim stanowiskiem twórcy konwencji haskiej z 1961 r. o formie rozrządzeń testamentowych w art. 5 uznali ograniczenia formy rozrządzeń testamentowych związane $\mathrm{z}$ wiekiem, obywatelstwem lub innymi przymiotami osobistymi testatora, za należące do zakresu formy.

W literaturze proponowano ${ }^{49}$ jednak również inną ocenę art. 992 k.c. holenderskiego. Sugerowano więc aby przepisowi temu nada-

${ }^{47}$ Por. R.R. NEUnER, Der Sinn der internationalprivatrechtlichen Norm, Brünn-Prag-Leipzig-Wien 1932, s. 28 i n.; W. Niederer, Die Frage der Qualifikation als Grundproblem des internationalen Privatrechts, Zürich 1940, s. 9 i n.; H.P. GLENN, La capacité de la personne en droit international privé français et anglais, Paris 1975, s. 197 nr 232; A. MĄCZYŃsKI, Dziedziczenie, cit., s. 89 i n.

${ }^{48}$ E. BARTIN, De l'impossibilité d'arriver à la suppression définitive des conflits de lois, «Journal du droit international»1897, s. 223; TENżE, Principes de droit international privé, I, Paris 1930, s. 225.

${ }^{49}$ Poglądy te omawia A. MĄCZYŃsKI, Dziedziczenie, cit., s. 91 i n. 
wać charakter kolizyjnoprawny i traktować jako wyjątek od zasady locus regit actum. Przy takim podejściu przepis ten stosowałyby jedynie sądy holenderskie (zgodnie z zasadą, że sądy danego państwa stosują własne normy kolizyjne prawa prywatnego międzynarodowego), nie byłby zaś stosowany przez sądy innych państw.

Podobne wątpliwości powstają przy rozpatrywaniu ograniczeń formy testamentu w związku $\mathrm{z}$ osiągnięciem odpowiedniego wieku.

3. W związku ze zróżnicowanym podejściem poszczególnych systemów prawnych do kwestii dopuszczalności testamentów wspólnych nasuwa się pytanie, czy chodzi tu o ograniczenie dotyczące formy testamentu czy też ograniczenie jego treści. Postanowienie art. 4 konwencji haskiej z 1961 r. rozstrzyga to pytanie na korzyść formy. Wypowiedzi idące w podobnym kierunku napotkać można w literaturze i judykaturze niektórych państw ${ }^{50}$. Jest to prawidłowy tok rozumowania.

4. Nie zalicza się do zakresu formy wymagania wpisu do odpowiedniego rejestru ${ }^{51}$ (np. do Krajowego Rejestru Sądowego, ksiąg wieczystych, rejestru zastawów, ksiąg stanu cywilnego). Chodzi w tych przypadkach o wymaganie materialnoprawne, podlegające legi causae (czyli prawu właściwemu dla czynności prawnej, której skutki mają być w rejestrze ujawnione lub prawu właściwemu dla prawa podmiotowego o którego nabycie chodzi). Co do kwestii proceduralnych związanych $\mathrm{z}$ wpisem stosować należy lex fori processualis.

5. Także wymaganie zgody osoby trzeciej (np. współmałżonka) lub organu państwowego na dokonanie określonej czynności prawnej należy traktować jako materialnoprawną przesłankę od której zależą określone skutki prawne, ocenianą wedle miarodajnego dla

${ }^{50}$ Por. A. MĄCZYŃsKi, Dziedziczenie, cit., s. 100 i n.; TENżE, Kolizyjna problematyka czynności prawnych na wypadek śmierci (zagadnienia wybrane), «Krakowskie Studia Prawnicze» 12 (1979), s. 79; M. PAZDAN, Czynności notarialne w międzynarodowym prawie spadkowym, «Rejent» 8.4 (1998), s. 106 i 107 i literatura oraz judykatura tam przytoczona.

${ }^{\text {s1 }}$ Por. W. PopIOŁeK, Umowa wydawnicza, cit., s. 106. 
niej prawa, a nie jako wymaganie dotyczące formy, oceniane według statutu formy czynności prawnej. W przypadku zgody współmałżonka owym prawem miarodajnym jest statut stosunków majątkowych małżeńskich. Z kolei wymaganie zgody przedstawiciela ustawowego na dokonanie czynności prawnej przez pupila podlega statutowi personalnemu pupila. Przedstawiciela ustawowego nie można bowiem uważać za osobę trzecią, a jego udział przy dokonaniu czynności prawnej wynika z konieczności zapewnienia ograniczonemu w zdolności do czynności prawidłowej reprezentacji, gdy pragnie on uczestniczyć w obrocie.

Podobnie też wymaganie zgody Walnego Zgromadzenia na dokonanie określonej czynności prawnej przez spółkę wynikać może ze statutu personalnego danej spółki i temu statutowi podlega.

Form of Legal ACt in Private International LaW

\section{Summary}

The form of a legal act in private international law is usually governed by particular conflict rules. Such provisions define the scope of their application. The aim of conflict rules is to indicate territorial application of different legal systems. That function fixes the approach while determining the way of understanding the notion of a "form" in private international law. The appropriate approach is the autonomic qualification. That is why I admit that the form in private international law is nothing else that the way of submission and incorporation of the declaration of will, being a component of a legal act.

According to art. 12 of Polish Act on private international law from 1965 (1965 Act), the form of a legal act is governed by the law proper for that act (the first rule), however, it is sufficient to fulfill the conditions of the law of the country where the legal act is undertaken (the second rule).

Lex causa, relevant to the form of a legal act (art. 12 section 1 of 1965 Act), may be indicated not only by means of conflict rules based on 
objective factors of a lien, but also by the choice - of - law clause (if a choice of law is not forbidden). Nevertheless, a choice of law regarding solely the form of a legal act is not acceptable. The choice of law for the form of a legal act cannot be justified by the permissibility of a partial choice of law, which is supposed to be a choice relative to that part of legis causae, which is taken into consideration while determining the conditions required for the form of a particular legal act, on the base of art. 12 section 11965 Act. Although, there is no fragment of the legis causae applied in the scope of the form, there is complete lex causae or divided into segments (in the case of a complex or simple choice of law). The form cannot constitute such a segment. It has its own status.

The second rule is subsidiary to the first one.

The mutual relation of these two rules has subsequent consequences:

1 lex loci actus may be applied only when the conditions of lex causae were not fulfilled;

2 the answer to the question if the legis loci actus constitutes the proper law for the form of a legal act is dependent on the fact whether during the performance of the legal act the requirements resulting from that law were fulfilled;

3 when the conditions regulated by both lex causae as well as lex loci actus were not fulfilled, it is to lex causae to decide about the consequences (sanctions) of non - fulfillment of the requirements relating to the form;

4 lex loci actus cannot be replaced by the Polish law by the virtue of art. 7 of 1965 Act, when the content of the law binding on the territory where the legal action was undertaken cannot be determined;

5 the transmission and remission, based on the conflict rules binding in that country where the legal act was undertaken, is not allowed;

6 the requirements of legis loci actus are also fulfilled when there are no special requirements relating to the form. The legal act will be valid in such a situation although the requirements relating to the form, resulting of lex causae, were not fulfilled.

The place where the legal act is performed understood as the factor of a lien in art. 12 section 2 of 1965 Act must be interpreted in the light of autonomic qualification. The decisive role should be granted to the place where an event which brought (or should have brought) to the 
performance of a legal act had happened while the contractual relation has been formed.

De lege ferenda, I am opting for the maintenance of both rules in Polish law, however, their position should be equal. In case of discrepancy of the effects the preference should be granted to those more favorable for the legal act (the solution in favorem negotii). 